\title{
UJI BANDING ANTAR LABORATORIUM DALAM PENGUKURAN RADIOAKTIVITAS MENGGUNAKAN SPEKTROMETER GAMA
}

\author{
Maskur, Adang H.G., Endang Sarmini, Yayan Tahyan, Dede Kurniasih \\ PRR-BATAN Serpong-Tangerang Selatan \\ E-mail: maskur@batan.go.id
}

\begin{abstract}
ABSTRAK
UJI BANDING ANTAR LABORATORIUM DALAM PENGUKURAN RADIOAKTIVITAS MENGGUNAKAN SPEKTROMETER GAMA. Lahoratorium Uji Radioisotop dan Radiofarmaka (LUR2) adalah laboratorium uji milik Pusat Radioisotop dan Radiofarmaka BATAN yang tclah memperoleh akreditasi ISO/IEC 17025 dari KAN (Komite Akreditasi Nasional), Sesuai aturan ISO/IEC tersebut, maka laboratorium secara berkala harus melakukan validasĭ metode dan sałahsalu caranya melalui uji banding antar laboratorium. Pada tahus 2012, LUR2 telah mengikuti uji banding antar laboratorium di BATAN yang dikoordinir PTKMR tentang pengukuran radioaktivitas menggunakan spektrometer gama, sampel berupa radionuklida Eu-152, Uji Bandang dikuti olch 16 peserta yang berasal dari laboratorium di BATAN dan basil pengukuran menunjukkan mayoritas laboratorium mempunyai penyimpangan $=10 \%$ dibanding nilai acuan. Pada awainya LUR2 melakukan pengukuran menggunakan perbandingan net area sampel dan sumber standar Eu-152. Hasil pengukuran ternyati selisih 5 kali lebih besar dari nilai acuan. Untuk pembandirg maka dilakukan pengukuran ulang menggunakan sumber standar lain (kombmasi Ba-133, Co-60, dan C4-137) ternyata hasil pengukuran mempunyai sclisih mendekati nilai acuan. Lntuk konfirmasi lebih lanjut. maka sumber standar Eu-152 diakur akitivitasnya menggunakan sumber standar lain (kombinasi Ba-133, Co-60, dan Cs-137/ dan ternyata hasilnya 1/5 dari aktivitis yang tertera di sertifikat. Hasil ini menunjukkan bahwa sumber penyimpangan besar bukan pada alat melainlan karena radioaktivitas yang tertera di sertifikat sumber standar Eu-152 tidak sesuai dengan tadioaktivitas yang sebenarnya. Dari hasil kegiatan ini, disimpulkan bahwa uji banding antar laboratorium sangat penting karena dapar mengelahus dengar segeru jika ada penyimpangan pada alat maupun sertifikat sumber standar-
\end{abstract}

Kata Kunci: Uji batiding, pengukuran radioaktivitas, sumber standar, spektrometer gama x-cooler

\section{ABSTRACT}

INTERLABORATORY COMPARISONS IN THE MEASUREMENT OF RADIOACTIVITY USING GAMMA SPECTROMETER. Radioisotopes und Radioharmaceuticals Testing Laboratom ALUR27 is a festing laboratory owed by Cenfer for Radioisolopes and Radiopharmaceuticals BATAN that has offained accreditations to ISO IEC 17025 from KAN According to the nACE of ISO IEC, the laboralong should periodically validate methodx and one of the main way through labonatory intercamparison. Im 2012, LLR2, have folfonved interlaboratony comparisons in BATAN courdinated by PTKMR aboud radiowivity meuvarements using gamma spehtrometer with sumples of radionuclide Ex-152. Comparative trials folloned hy 16 partioipants from laboratories in BATAN and measurement results showed the majority of laborutories had deviation <10\% eompore to the reference slandard. At first LURZ measure net area ratio of the sample and the standard Fu-152 swirce. The metasianemt gave the difference of +5 times greater than refercnce valte For comparison of the measurements was penformed using other stamdand sources fa combination of Ba-133. Co-60 and C.s-137). The result of measurement was clase to the reference value. To ohtain reliabihity for finther confirmution, the standard semurce of Eu-152 activisy was measured using other standard sources fa combination of $B a-133, \mathrm{Co}-60$ and $\mathrm{Cs-137)}$ and the resuls was one fifth of the activities in the certificale. These resulss udicate hat the major sontree of deviation did nor originate from the equipment but rather becanse of the radious rivity contained in the certificate of El/-152 standard source does not correspand to the actual radioactivify. From the results of this project. it wess conclided that 
wterlaboratory compansans is ven importan becatwe it can derermine immediately if there are devation in the instruatent of certifictate srandard sources.

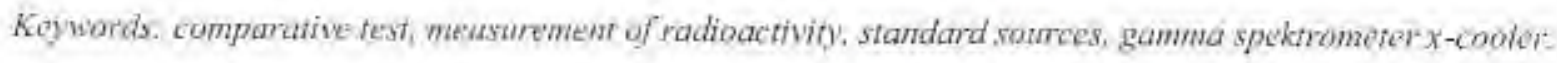

\section{PENDAHULUAN}

Spektrometer gamma merupakan alá yang dapat digunakan untuk menganalisis sumber radioaktif untuk mengidentifikasi unsur atau isotop-isotop radioaktif yang ada di dalamnya. Seperangkat spektrometergamma terdíri beberapa sub system seperti detektor gamma, rangkaian elektronika. catu daya tegangan tinggi, rangkaîn MCA yang tcrintegrasi dan on board pada slot CPU. serta dilengkapi perangkat lunak untuk proses data [1]

Laboratorium Uji Radioisotop dan Radjofarmaka (LUR2) adalah laboratorium uji movilk instansi Pusat Radioisotop dan Radiofarmaka BATAN yang télah memperoleh akreditasi ISO/IEC 17025 dari KAN dengan nomer sertifikat LP-595-IDN/25 April 2012. Oleh karena itน, seluruh sistem mutu LUR2 harus mengacu pada aturan ISO/IEC 17025.

Berdasakan standar sistem mutu ISO/IEC 17025:2005 yang menggantikan ISO/IEC 17025:1999, lerjadi perubahan persyaratan teknis jaminan mutu hasil analisis pada sub klausul 5.9.2. yang menyatakan data pengendalian mutu harus dianalisis dan bila ditenukan diluar kriteria, tindakan tertentu harus dilakukan untuk mengoreksi permasalahan dan meneegah pelaporan hasil yang salah ${ }^{[2] \mid 3\}}$.

\section{Laboratorium}

Standarisasi

Radionuklida PTKMR BATAN merupakan Laboralorium Metrologi Radiasi sebagai laboratorium acuan nasional di bidang pengukuran radioaltivitas ${ }^{|4|}$ Oleh karena itu, untuk menjamin pemastian mulu hasil pengujian sesuai ketentuan 1SO 17025:2005 maka LUR2 pada tahun 2012 telah mengikuti kegiatan interkomparasi antar laboratorium di BATAN yang dikoordinir oleb PTKMR BATAN dalam pengukuran radioaktivitas menggunakan spektrometer gama. Adapun peralatan spektrometer gama di PRR seperti ditunjukkan pada Gambar 1.

Diharapkan dari hasil interkomparasi ini, LUR2 dapat mengukur seberapa besar penyimpangangan akurasi dose calibrator milik LUR2 dibanding laboratorium acusn.

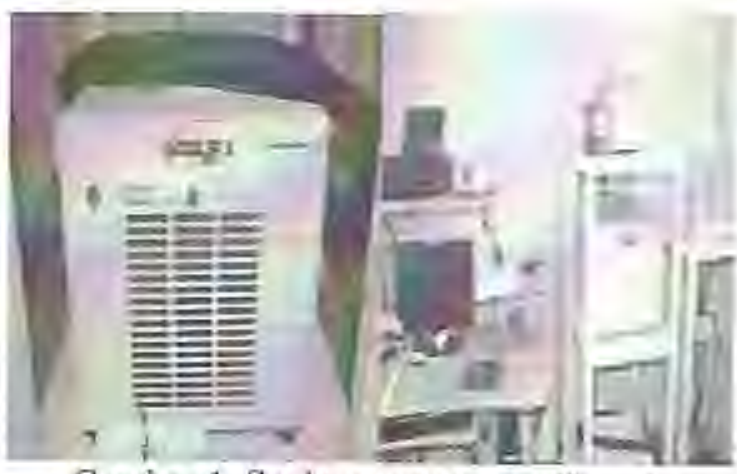

Gambar 1. Spektrometergama $X$-cooler

Pengolahan datà secara kuantitatif cuplikan pemancar sinar gama yang diukur. harus dibuat kurva kalibrasi efisiensi menggunakan sumber standar pemancar sinar gama. Pengolahan data untuk pembuatan kurva kalibrasi efisiensi harus dilakukan sebaik mungkin karena setiap perhiturigan cuplikan yang diukur mengacu pada kurva int. Untuk mengetahui kinerja peralatan spektrometer gama yang digunakan, perlu dibuat control chart dengan mengukur suatu sumber standar pemancar sinar gama beberapa kali pada posisi yang sama dan dihitung simpangan bakunya. Selanjutnya control chart ini dipakai untuk memeriksa apakah peralatan spcktrometer gama dalatn kondisi optimurn sebelum digunakati untuk pengukuran ${ }^{[s]}$

Sebelum pembuatan kurva kalibrasi efisiensi, maka terlebih dahulu dilakukan pengukuran sumber standar radioaktif yang diketahui radioaktivitasnya (dps) Dari spektrum gama dapat diketahui cps (counts per secondf) dari setiap puncak pada energi tertentu dengan mencari het area dari puncak tersebut dibagi dengan counting time (dalam detik). Dengan demikian dapat dicari efisiensi pengukuran pada energi dan geometri tertentu dengan rumus :

$$
E f=\frac{c p s}{D p s . l}
$$

Dengan $E f=$ efisiensi pengukuran, $C \mathrm{ps}=\mathrm{cacah}$ per detik, $D p s=$ peluruhan per detik, $I=$ intensilas (abundance) 
Intensitas (abundance) dari suacu energi sinar gama adalah fraksi (persentase) dari setiap laju peluruhan (dps) yang memberikan kontribusi pada energi tersebut. Hai ini dapat dilihat dari tabel energi sinar gama ${ }^{15161}$

Pada kurva kalibrasi efisiensi, sebagai absis adalah energi (keV) dan ordinat adalah efisiensi. Persamaan untuk energi $>100 \mathrm{keV}$ ini. bisa memiliki karakteristik persamaan power yang meniliki bentuk umum.

$$
Y=A X^{B}
$$

dengan $Y$ adalah efisiensi dan $X$ adalah energi. A dan $B$ adalah nilai yang diperoleh dari persamaan kurva katibrasi efisiensi energy sumber standard dan selanjutnya akan dipergunakan untuk menghitung efísiensi sampel menggunakan persamaan power.

Setelah diperoleh kurva kalibrasi efisiensi energy dari sumber standar dan datadata pengukuran sampel berupá net area, waktu counting, efísiensi dan intensitas maka radioaktivitas dari radionuklida dapat dihitung dengan menggunakan persamaan 1 maupun rasio net area antara sampel dan sumber standar.

\section{METODE}

Bahan

Bahan utana yang digunakan dalam kegiatan ini adalah Sumber standar Eu-152, Ba-133, Cs137. Co-60, sampel Eu-152 dari PTKMR untuk interkomparasi yang akan diukur radioaktivitastyya.

\section{Peralatan}

Seperangkat insirumen spekrometer gamma xcooler Spektrometer Gama dengan pendinginan detektor sistem elektrik Spesifikasi : ORTEC, HPGe detektor with Xcooler system $\left(\mathrm{Na}_{\mathrm{L}} \mathrm{LN}_{2} /\right.$ No Dewar filling operations) Mechanical dimension: Compressor: $12.5^{\text {th }} \mathrm{W} \times 12.5^{\text {" }} \mathrm{D} \times 1 \mathrm{I}^{\mathrm{N}} \mathrm{H}$ Cold head length with detektor capsule attached stanciard 23.25" Weight = compressor - 36 I Cold head: 11 lbs (not include capsule)

\section{Persiapan Alat:}

Dipastikan semua tegangan listrik sesuai dengan yang direkomendasikan alat (220 VAC). Pendingin X-cooler ditempatkan pada posisi datar dan stabil. Apabila terjadi perpindaban tempat disaranksan untuk didiamkàn terlebih dahula selama minimai 24 jam agar oli di dalam mesiu dalam kondisi stabil. Disambungkan semua konektor dengan benar dan diperiksa kembati

\section{Proses Pendinginan:}

Stabilizer dan UPS dihidupkan, dipastikan pengisian baterai berjalan normal. Cryosecure dihidupkan, Jampu indikator akan menyala dan berkedip, system akan booting otomatis, ditunggu 10 menit untuk pengisian internal baterai. Initialize ditekan selama kurang lebih 5 detik maka cryosecure akan self detect. Proses cooling down detektor telah dimulai, ditunggu sampai $14 \mathrm{jam}$

\section{Proses Inisialisasi Sistem:}

Dipastikan lampu indikator Cryosecare yang menyala hanya power. Dikik start windows, dipilih Maestro 32. dipilih $M C B$ Configuration. Diklik deteksi MCB yang ada kemudian diklik Renewal All, Close. Diklik icon Macstri-32, dipilih menu acquire, lalu dipilih $M C B$ propertise. Diseting amplitier, dipilih Polarity $(-)$, sesuai dengan tipe detektor, dipilih pre amp Resistor feedback sesuai dengan detektor P4. Disetting HV isi tegangan kerja $3500 \mathrm{~V}$, dipilih shutdown method ORTEC, ditekan tobol ON maka bias detektor telah dimular, ditunggu selama 30 menit agar tegangan hias stabil. Dipilih menu optimise pada amplifier, diekan autostart maka penganturan signal akan berjalan otomatis, ditunggu I sampai i0 menil hingga bunyi beep tanda selesai. Dipilih preset unnak mengatur waktu cacah yang kita inginkan.

\section{Proses Akuisisi Data (Pengukuran):}

Diklik icon Maestro-32 untuk mengaktifkan sistem. Sampel (sumber radiøaktif) yang akan diakuisisi dimempatkan di dalam perisai detektor. Dilakukan akuisisi dengan menekan icon GO. ditunggu sampai proses cucah selesai. Diklik menu ROI untuk menentukan ROI pada peak energi. Dilakukan olah data lebih lanjut dengan menekan menu yang tersedia. Dipilih menu Aequire, kemudian clear untuk menghapus data yang telah diambil. Dilakukan aluisisi seperti langkah di atas, dipilih menu Tile, save untuk menyimpan. Jika pengukuran telah selesai maka komputer dishutdown. Dimstikan seluruh Power Supply ke OFF 


\section{Pembuatan control chart spektrometer gama.}

Dilakukan pengukuran aktivitas sumber standar Eu-152 menggunakan spektrometer gamma Pengukuran dilakukan 10 kali pengukuran setiap bulan dan dilakukan selama 3 bulan. Aktivitas hasil pengukuran dihitung peluruhannya berdasarkan basis tanggal tertentu. Hasil pengukuran diolah datanya menggunakan excell hingga diperoleh control chart dari instrumen.

\section{Interkomparasí pengukuran spektrometer gamma antar laboratorium di BATAN:}

Sumber standar Fu-152 diukur menggunakan spektrometer gamma. Dibuat kalibrasi efisiensi energi berdasarkan sumber standar Eu-152. Diukur sampel dari koordinator interkomparasi. Dilakukan cara yang sama dari a sampai c, tetapi sumber standar yang digunakan adalati kombinasi dari sumber standar Cs-137, Ba-133, dan Co-60. Dihitung aktivitas sampel berdasarkan sumber statidar Eu-152 dan sumber standar kombinasi Cs-137. Ba-133, dan Co-60 lalu dibandingkan hasilnya. Dibuat laporan interkomparasi untuk dibandingkan dengan hasil dari laboratorium yang lain.

\section{HASIL DAN PEMBAHASAN}

Interkomparasi antar laboratorium seluruh BATAN yang dikoordinasi oleh PTKMR pada tahun 2012 dalam pengukuran Aktivitas sampel Eu-152 yang didistribusikan olch PTKMR dengan menggunakan instrument spektrometer gama.Interkomparasi diikuti 16 peserta laboratorium laboratorium di BATAN. Untuk memastikan alat ukur yang digunakan dalam kondisi baik maka secara berkala dibuat tontrol chan alat spektrometer gama seperti ditunjukkan pada Gambar 2.

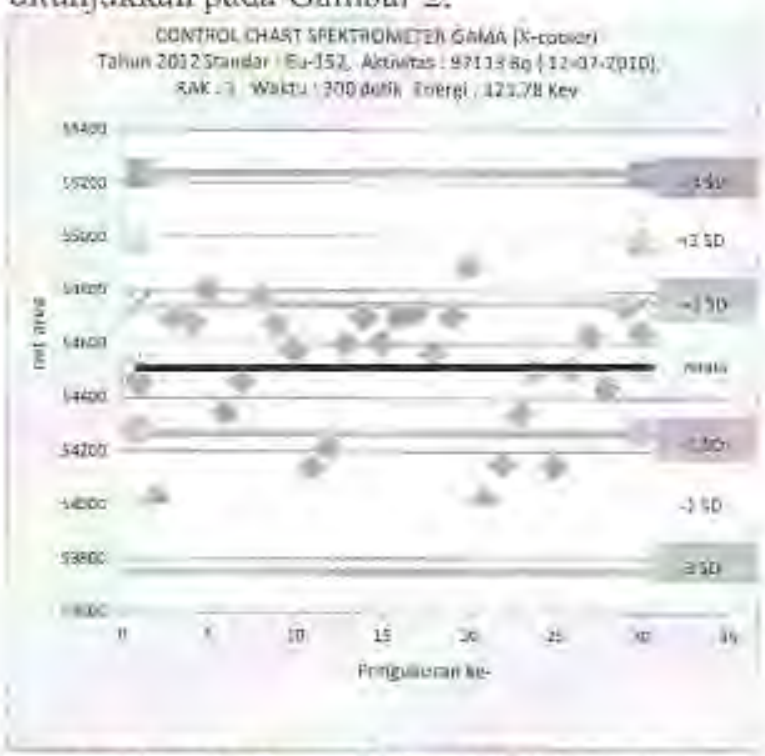

Gambar 2. Control Chart Spektrometer Gamma X-cooler tahun 2012

Dari Gambar 2 ditunjukkan hasil control cahart spektrogama $x$-cooler milik LUR2-PRR pada tahun 2012 Control chart ini sangat burmanfaat untuk melilat kinerja alat. terutama dalam hal presisi pengukuran. Dari control chart tersebut, diketahui bahwa $80 \%$ data pengukuran berada pada daerah $\pm 1 S D$ dan $20 \%$ berada $\pm 2 S D$. Hal ini menunjukkan bahwa alat spektrometer gama mempunyai presisi baik, sehingga siap untuk digunakan pengukuran radioaktivitas.

Pada pengukuran radioaktivitas sampel Eu-152 ini, digunakan sumber standar Eu-152, C0-60, Ba-133, dam Cs-137. Adapun data secara lengkap diturijukkan pada Tabel I:

Tabel 1. Data sumber tadionuklida stàndárd dan sampel

\begin{tabular}{|c|c|c|}
\hline $\begin{array}{c}\text { Sampel yang akan } \\
\text { diukur } \\
\text { radioaktivitasnya }\end{array}$ & Eu-152 & $\begin{array}{l}\text { Waktu } \\
\text { Paruh }\end{array}$ \\
\hline $\begin{array}{l}\text { Aktivitas Sumber } \\
\text { standar Eu-152 }\end{array}$ & $\begin{array}{l}97113 \mathrm{~Bq} \pm 5,0 \mathrm{~S} \% \\
(12-j u t i-2010) \text { No.serifikat } 024 / \mathrm{S} / \mathrm{P} 10301 / \mathrm{KMR} / 2010\end{array}$ & $\begin{array}{l}13,522 \\
\text { tahum }\end{array}$ \\
\hline $\begin{array}{l}\text { Aktivitas Sumber } \\
\text { standar } \mathrm{Ba}-133 \\
\text { Aktivitas Sumber } \\
\text { standar } \mathrm{C} s-137 \\
\text { Aktivitas Sumber } \\
\text { standar } \mathrm{Co}-60 \\
\text { Tanggal Acuan } \\
\text { Perhitungan }\end{array}$ & 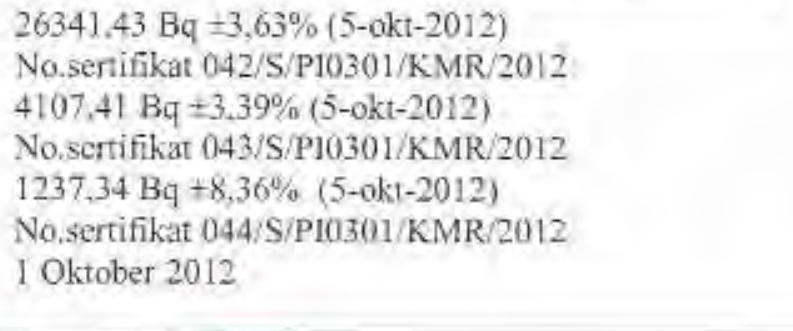 & $\begin{array}{c}10,540 \\
\text { tahun } \\
30,05 \\
\text { tahun } \\
5,2711 \\
\text { tahun }\end{array}$ \\
\hline
\end{tabular}




\section{Data Pengukuran}

\section{Sumber Standar}

Hasil pencacahan sumber standard multi gamma Eu-152 ditunjukkan pada Gambar 3 dan Tabel 2.

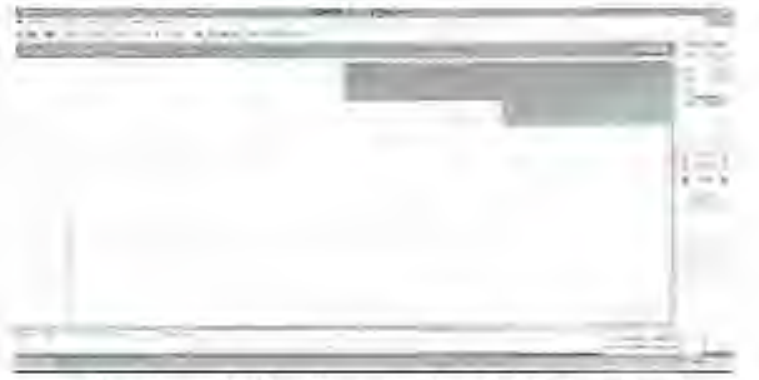

Gambar 3. Spektrum Sumber standar Eu152 menggunakan Spektrometer Gamma

Tabel 2. Hasil Pencacahan Sumber standar

Eu-152, Waktu Pencacahan 3600 detik

\begin{tabular}{llll}
\hline No & $\begin{array}{l}\text { Net } \\
\text { Area }\end{array}$ & FWHM & $\begin{array}{l}\text { keV } \\
\text { (centroid) }\end{array}$ \\
\hline 1 & 101280 & 2,06 & 122,06 \\
2 & 12553 & 1,92 & 244,7 \\
3 & 35228 & 1,96 & $3,44,28$ \\
4 & 7306 & 2,14 & 778,9 \\
5 & 7295 & 2,44 & 964,13 \\
6 & 5675 & 2,43 & 1112,12 \\
7 & 6833 & 2,45 & 1407.98 \\
\hline
\end{tabular}

\section{Beberapa Sampel Sumber Radioaktif dari koordinator interkomparasi}

Pada interkomparasi ini telah diberikan oleh koordinator beberapa sampel sumber radioaktif sepert Eu-152, Ba-133, Cs-137dan C0-60 pada penulis. Hasil pencacahan sampel Eu-152 dari koordinator interkomparasi ditampilkan pada Tabel 3 .

Tabel 3. Hasil Sampel Interkomparasi

Eu-152, Waktu Pencacahan 3600 detik

\begin{tabular}{llll}
\hline No & $\begin{array}{l}\text { Net } \\
\text { Area }\end{array}$ & FWHM & $\begin{array}{l}\text { keV } \\
\text { (centroid) })\end{array}$ \\
\hline 1 & 190759 & 2,05 & 122,02 \\
2 & 23687 & 1,89 & 244,68 \\
3 & 65693 & 2,00 & 344,05 \\
4 & 13493 & 2,07 & 778,86 \\
5 & 13301 & 2,34 & 963,84 \\
6 & 10411 & 2,26 & 1111,77 \\
7 & 12748 & 2,42 & 1407,52 \\
\hline
\end{tabular}

Tabel 3 hasil cacahan Eu-152 menggunakan spektrometer gamma $\mathrm{x}$-cooler dan ternyata terdeteksi tujuh puncak dengan tingkat energi yang berbeda dengan rentang energi yang besar. Hal ini yang menyebabkan sumber standar Eu-152 disebut sumber standar multi energi dan dapat digunakan untuk kalibrasi efisiensi.

Hasil pencacahan sampel Ba-133 dari koordinator interkomparasi ditampilkan pada Gambar 4 dan Tabel 4.

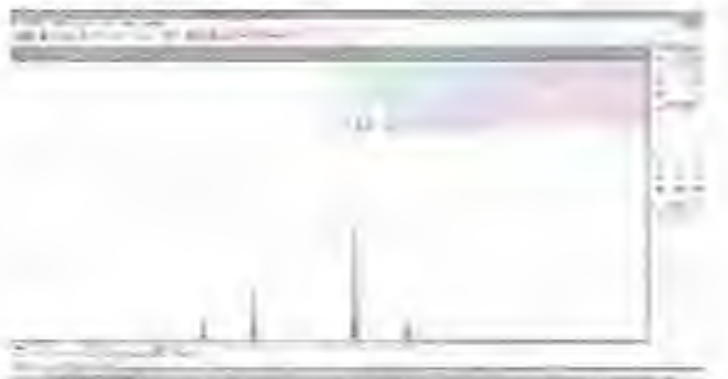

Gambar 4. Sampel Interkomparasi Ba-133 menggunakan Spektrometer Gamma

Tabel 4. Hasil Sampel Interkomparasi Ba-133. Waktu Pencacahan 3600 detik

\begin{tabular}{lrll}
\hline No & $\begin{array}{l}\text { Net } \\
\text { Area }\end{array}$ & FWHM & $\begin{array}{l}\mathrm{keV} \\
\text { (centroid) }\end{array}$ \\
\hline 1 & 18550 & 1,98 & 276,33 \\
2 & 43171 & 1,92 & 302,73 \\
3 & 126349 & 1,98 & 355,76 \\
4 & 15277 & 1.94 & 383,56 \\
\hline
\end{tabular}

Pada Gambar 4 dan Tabel 4 ditunjukkan spektrum Ba-133 yang diukur menggunakan spektrometer gama $\mathrm{x}$-cooler dan ternyata terdeteksi empat puncak dengan tingkat energy yang berbeda dengan rentang energi yang sempit. Hal ini yang menyebabkan sumber standar $\mathrm{Ba}-133$ tidak dapat dijadikan sumber standar tunggal untuk kalibrasi efisiensi, tapi harus dikombinasikan dengan sumber standar yang lain yaitu biasanya Cs137 dan Co-60.

Hasil pencacahan sampel $\mathrm{Cs}_{\mathrm{S}} 137$ dari koordinator interkomparasi ditampilkan pada Gambar 5 dan Tabel 5 .

Tabel 5. Hasil Sampel Interkomparasi Cs-137, Waktu Pencacahan 3600 detik

\begin{tabular}{llll}
\hline No & $\begin{array}{l}\text { Net } \\
\text { Area }\end{array}$ & FWHM & $\begin{array}{l}\mathrm{keV} \\
(\text { centroid })\end{array}$ \\
\hline $\mathrm{I}$ & 14299 & 2,11 & 661,72 \\
\hline
\end{tabular}




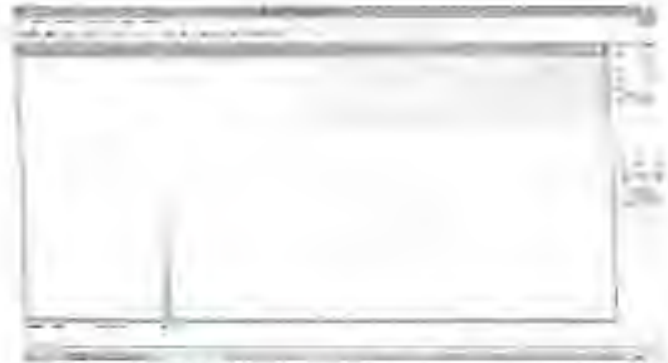

Gambar 5. Sampel Interkomparasi Cs-137 menggunakan Spektrometer Gamma

Pada Gambar 5 dan Tabel 5 memperlihatkan spektrum Cs-137 yang diukur menggunakan spektrometer gama $\mathrm{x}$-cooler dat ternyata terdeteksi puncak tunggal dengan tingkat energi $661,72 \mathrm{kev}$. Oleh karena itu sumber standar Cs-137 tidak dapat dijadikan sumber standar tunggal untuk kalibrasi efísiensi, tetapi harus dikombinasikan dengan sumber standar yang lain biasanya $\mathrm{Ba}-133$ dan $\mathrm{Co}-60$.

Hasil pencacahan sampel Co-60 dari koordinator interkomparasi ditampilkan pada Gambar 6 dan Tabel 6.

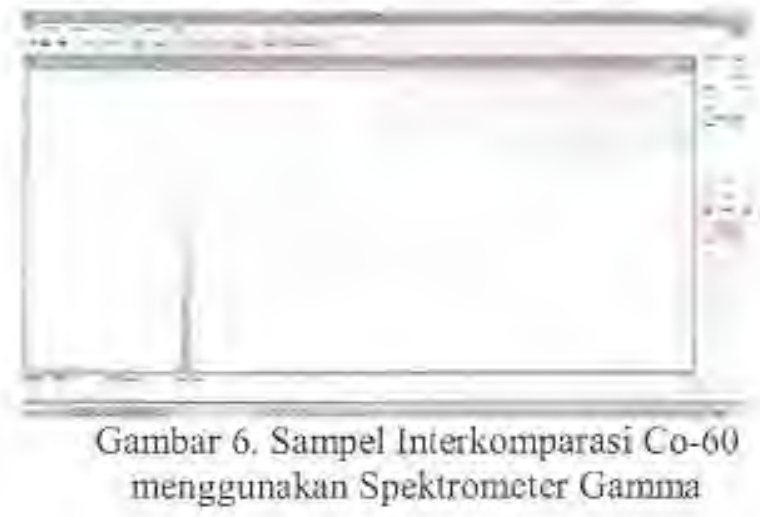

Tabel 6. Hasil Sampel Interkomparasi Co-60, Waktu Pencacahan 3600 detik

\begin{tabular}{llll}
\hline No & $\begin{array}{l}\text { Net } \\
\text { Area }\end{array}$ & EWHM & $\begin{array}{l}\mathrm{keV} \\
\text { (centroid) }\end{array}$ \\
\hline 1 & 2727 & 2,23 & 1173,01 \\
2 & 2286 & 2,60 & 1332,08 \\
\hline
\end{tabular}

Gambar 6 dan Tabel 6 ditunjukkan spektrum Co-60 yang diukur menggunakan spektrometer gamma $\mathrm{x}$-cooler dan ternyata terdeteksi hanya dua puncak yaitu dengan tingkat energi 1173.01 dan $1332,5 \mathrm{kev}$. Oleh karena itu sumber standar Ba-133 tidak dapat dijadikan sumber standar tunggal untuk kalibrasi efisiensi, tapi harus dikombinasikan dengan sumber standar yang lain biasanya $\mathrm{Ba}-\mathrm{I} 33$ dan $\mathrm{Cs}-137$.

\section{Perhitungan menggunakan sumber standar Eu-152 (Cara perbandingan net Area)}

Aktivitas Eu-152 standar berdasarkan sertifikat adalah $97113 \mathrm{~Bq}$ dan setelah dihitung peluruhannya, maka per tanggal 1 Oktober 2012 adalah $86648,7 \mathrm{~Bq}$. Kemudian sumber standar dan sampel Eu-152 diukur aktivitasnyá menggunakan spektrometer gamma dan hasilnya seperti ditunjukkan pada Tabel 7.

Tabel 7, Perhitungan aktivitas berdasarkan ratio net area

\begin{tabular}{lllllll}
\hline Energi & $\begin{array}{l}\text { Intensitas } \\
\text { No }\end{array}$ & $\begin{array}{l}\text { Net Area } \\
\text { Stan- } \\
\text { dar }\end{array}$ & $\begin{array}{l}\text { Sam- } \\
\text { pel }\end{array}$ & $\begin{array}{l}\text { Waktu } \\
\text { Cacah }\end{array}$ & $\begin{array}{c}\text { Aktivitas sampel } \\
\text { (rationet } \\
\text { area)/Bq } \\
(1-O k t-2012)\end{array}$ \\
\hline 1 & 121,78 & 28.2 & 101280 & 190759 & 3600 & $163201,2 \mathrm{I}$ \\
2 & 244,7 & 7,42 & 12553 & 23687 & 3600 & 163502,56 \\
3 & 344,27 & 26,4 & 35228 & 65693 & 3600 & 161582,06 \\
4 & 778,9 & 13 & 7306 & 13493 & 3600 & 160026,12 \\
5 & 964 & 14,48 & 7295 & 13301 & 3600 & 157986,88 \\
6 & 1112,1 & 13,55 & 5675 & 10411 & 3600 & 158960,28 \\
7 & 1407,9 & 20,7 & 6833 & 12748 & 3600 & 161656,31 \\
\hline
\end{tabular}

Nktivitas sampel Eu-152 rerata (berdasarkan perhitungan ratio net area) menggunakan sumber standar Fu-152 adalah $=161207.4 \mathrm{~Bq}$
Dari pengukuran dan perhitungan yang telah dilakukan ternyata diperoleh hasil bahwa aktivitas Eu-152 sampel dari koordinator interkomparasi sebesar $161207.4 \mathrm{~Bq}$. Namun, 
ketika dibandingkan hasil pengukuran dari laboratorium yang lain ternyata hasil tersebut $5 \times$ lebih besar. Untuk menelusuri dari mana sumber penyimpangannya maka sebagai pembanding dilakukan metode perhitungan menggunakan sumber standar Ba-133, Cs-137, dan Co-60. Perhitungan Cara kurva standar menggunakan sumber standar $\mathrm{Ba}-133$, Cs-137. dan Co-60. Setelah pengukuran sumber standar, maka efisiensi pengukuran dihitung menggunakan Persamaan (1) dan hasilnya ditunjukkan pada Tabel 8.

Tabel 8. Perhitungan efisiensi pengukuran

\begin{tabular}{llllll}
\hline No & Isotop & Energi & Intensitas & $\begin{array}{l}\text { Dps (Bq) } \\
(1-\text { okt-12) }\end{array}$ & $\begin{array}{l}\text { Efisiensi } \\
=\text { cps/dps } \\
\text { intensitas }\end{array}$ \\
\hline 1 & Ba-133 & 276,33 & 61,9 & 26360,42 & 0,0003157 \\
2 & Ba-133 & 302,73 & 18,4 & 26360,42 & 0,0024724 \\
3 & Ba-133 & 355,76 & 7,3 & 26360,42 & 0,0182387 \\
4 & Ba-133 & 383,56 & 8,9 & 26360,42 & 0,0018088 \\
5 & Cs-137 & 661,72 & 86 & 4108,45 & 0,0011241 \\
6 & Co-60 & 1173,02 & 99,88 & 1239,12 & 0,0006120 \\
7 & Co-60 & 1332,1 & 100 & 1239,12 & 0,0005124 \\
\hline
\end{tabular}

Dari data pada Tabel 8 maka dapat dibuat kurva kalibrasi seperti ditunjukkan pada Gambar 7. Dari Gambar 7 kurva kalibrasi efisiensi energi sumber standar, maka diperoleh persamaan power $\mathrm{Y}=\mathrm{AX} \mathrm{X}^{\mathrm{B}}$ $=1,0193 \mathrm{X}^{\mathrm{t} i 30}$ dengan $\mathrm{Y}$ adalah etisiensi pengukuran dan $\mathrm{X}$ adalah energi sehingga efisiensi dapat dihitung dan kemudian digunakan sebagai data untuk perhitungan radioaktivitas sampel dengan menggunakan Persamaan (2) dan hasilnya ditunjukkan pada Tabel 9 ,

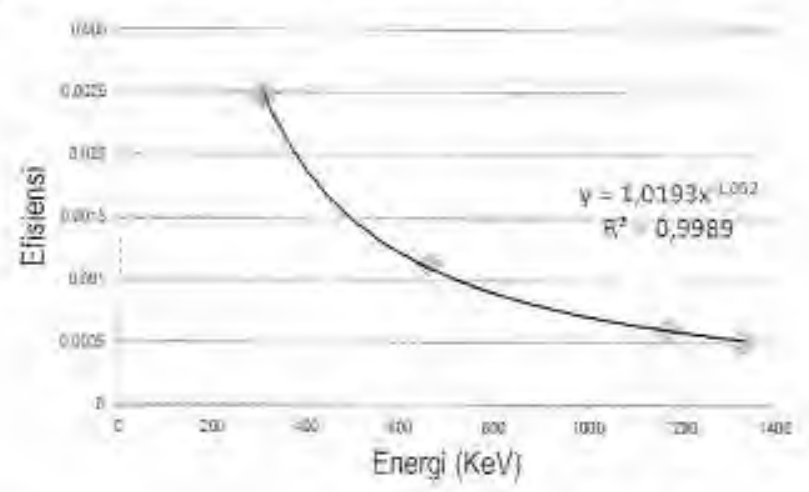

Gambar 7. Kurva kalibrasi Efisiensi Energi spektrometer gamma

Tabel 9. Perhitungan aktivitas sampel dari PTKMR menggunakan kurva kalibrasi Cs-137, Ba-133, dan Co-60

\begin{tabular}{cllcc}
\hline $\begin{array}{c}\text { Net area } \\
\text { sampel } \\
\text { waktu count }\end{array}$ & \multicolumn{1}{c}{ Energi } & $\begin{array}{c}\text { Intensit } \\
\text { as }\end{array}$ & $\begin{array}{c}\text { Efisiensi }=1.019^{*} \\
\text { (energi) } 11.052\end{array}$ & $\begin{array}{c}\text { Aktivitas Sampel } \\
(1-\text { Okt-12) }\end{array}$ \\
\hline 52,988 & 121,78 & 28,2 & 0,006520 & 28817,57 \\
6,579 & 244,7 & 7,42 & 0,003129 & 28336,39 \\
18,248 & 344,27 & 26,4 & 0,002185 & 31632,14 \\
3,748 & 778,9 & 13 & 0,000925 & 31145,79 \\
3,694 & 964 & 14,48 & 0,000739 & 34495,33 \\
2,891 & 1112,05 & 13,55 & 0,000636 & 33532,92 \\
3,541 & 1407,92 & 20,7 & 0,000496 & 34448,57 \\
\hline
\end{tabular}


Aktivitas sampel Eu-152 rerata menggunakan sumber standar C $5-137, \mathrm{Ba}-133$, dan $\mathrm{Co}-60$ $-3175632 \mathrm{~Bq}$ (1Oktober 2012)

Berdasarkan perhitungan metode yang kedua ternyata aktivitas sampel Eu-152 sebesar $31756.32 \mathrm{~Bq}$ dan ini jauh lebih kecil (sekitar 1/5) dibanding perhitungan menggunakan sumber standar Eu-152. Hal ini aneh, seharusnya perhitungan menggunakan sumber standar Eu-152 msupun gabungan sumber standar $\mathrm{Ba}-133$, Cs-137 dan Co-60 menghasilkan aktivilas yang sama.

Oleh karena itu, untuk menelusuri kesalahan apakah radioaktivitas sumber standar Eu-152 sesuai seperti yang lertera di sertifikat kalibrasi maka dilakukan pengukuran radioaktivitas sumber standar Eu-152 dengan menggunakan sumber standar lain yaitu gabungan $\mathrm{Ba}-133$, Cs-137 dan Co-60 dengan perhitungan menggunakan Persamaan (2) dan (3) hasilnya seperti ditunjukkan pada Tabel 10

Tabel 10. Perhitungan aktivitas Eu-152 standar menggunakan kurva kalibrasi Cs-137, Ba-133, dan Co-60

\begin{tabular}{cllcc}
\hline $\begin{array}{c}\text { Net area sampel } \\
\text { /waktu count }\end{array}$ & Energi & Inten sitas & $\begin{array}{c}\text { Efisiensi }=1.019^{*} \\
\text { (energi) } 1.052\end{array}$ & $\begin{array}{c}\text { Aktivitas Sampel } \\
(1-\text { okt-12) } \\
\text { (tret/wkt count)/ } \\
\text { (intensitas/100)/eff }\end{array}$ \\
\hline 28,13 & 121,78 & 28,2 & 0,00652 & 15300,16 \\
3,487 & 244,7 & 7,42 & 0,00313 & 15016,96 \\
9,786 & 344,27 & 26,4 & 0,00219 & 16962,80 \\
2,029 & 778,9 & 13 & 0,00093 & 16864,39 \\
2,026 & 964 & 14,48 & 0,00074 & 18919,13 \\
1,576 & 1112,05 & 13,55 & 0,00064 & 18278,68 \\
1,898 & 1407,92 & 20,7 & 0,00050 & 18464,63 \\
\hline
\end{tabular}

Berdasarkan perhitungan di atas ternyata aktivitas rerata sumber standar Eu-152 hasil perhitungan menggunakan sumber standar kombinasi Ba-133. Co-60. dan Cs-137 adalah $17081.12 \mathrm{~Bq}$ dan ini jauh lebih kecil dibanding aktivitas Eu-152 yang tertera di sertifikat, yaitu $97113 \mathrm{~Bq} \pm 5.08 \% \quad(12-\mathrm{juli}-2010)$ atau $86325.52 \mathrm{~Bq}$ (1-okt-2012). Perbedaan ini seharusnya tidak boleh terjadi. untuk mengkonfirmasi kebenarannya maka kami telah konfirmasi ulang ke stake holder yang mengeluarkan sertifikat sumber standar tersebut dan temyata memang ada kesalahan pada sertilikat.

Kesalahan nilai aktivitas sumber standar pada sertifikat ini berdampak fatal, karena kesalahan tersebut maka hasil interkomparasi pengukuran sampel menggunakan Spektrometer gama yang dilakukan PRR - BATAN pada tahun 2012 hasiltiya $161207.4 \mathrm{~Bq}$, jauh lebih besar $( \pm 5 \mathrm{x}$ ) dibandingkan hasil pengukuran laboratorium acuan, Namun, ketika dukur ulang dengan sumber standar kombinasi antara $\mathrm{Ba}-133, \mathrm{C} 5$ 137, Co-60 ternyata aktivitas sampel hasil pengukuran adalah $31756.32 \mathrm{~Bq}$ (1-oktober
2012) dan hasil ini mendekati hasil pengukuran laboratorium acuan.

Adapun basil interkomparasi antar laboratorium di BATAN dalam pengukuran tadioaktivitas Eu-152 yang dikoordinir PTKMR-BATAN pada tahun 2012 selengkapnya ditunjukkan pada Gambar 5 berikut ini: 


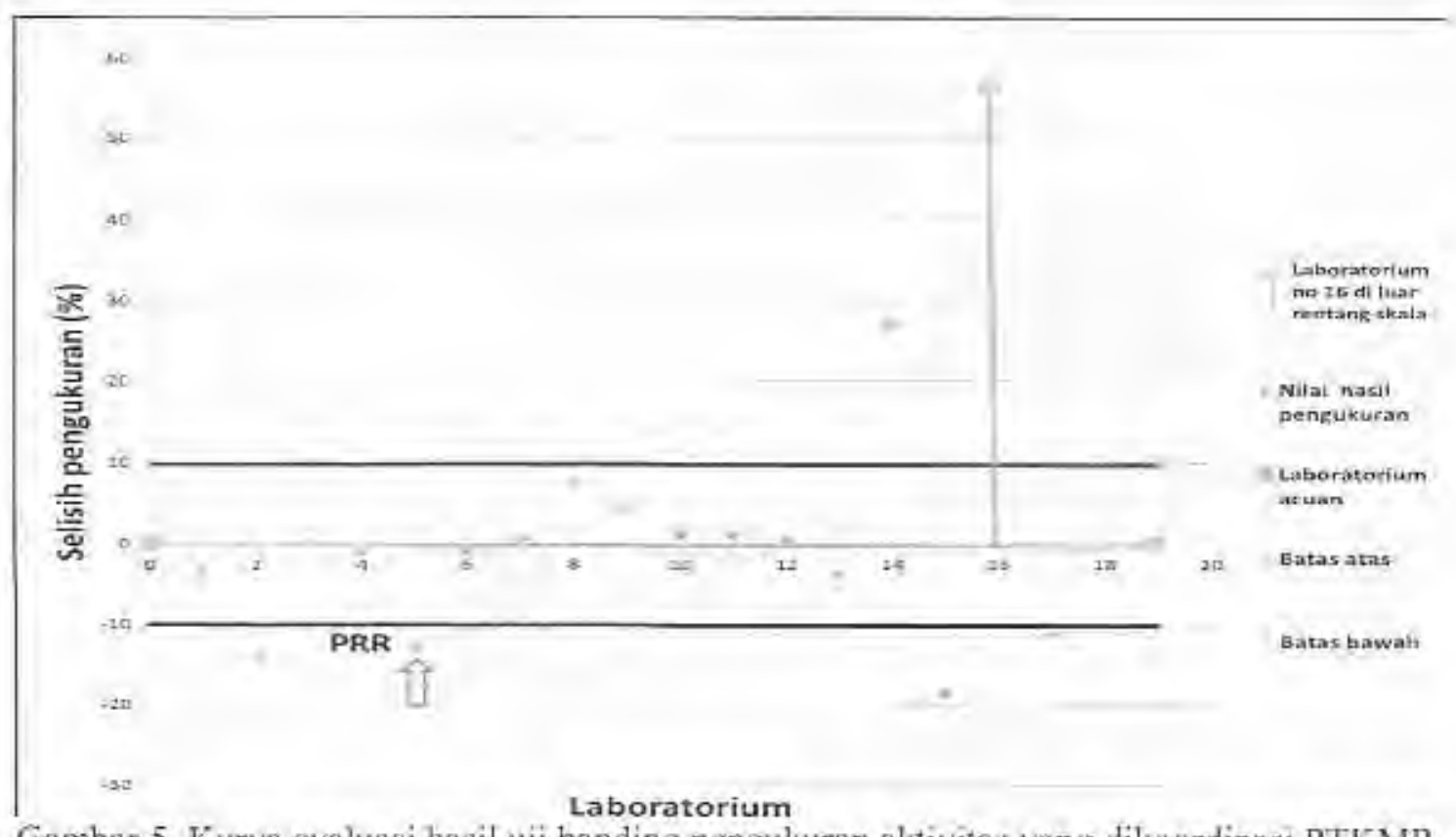

Gambar 5. Kurva evaluasi hasil uji banding pengukuran aktivitas yang dikoordinasi PTKMR (Sumber: Gatot Wurdiyanto et al, , 2012)

Pada Gambar 5 ditunjukkan bahwa kegiatan uji banding pengukuran radioaktivitas yang dikoordinasi PTKMR pada tahun 2012 diikuti oleh 17 peserta berbagai laboratorium di BATAN. Pada Gambar 5 sengaja tidak ditampilkan nama laboratoriumnya, namun datanya ada di PTKMR. Garis hijau di tengah. merupakan nilai aktivitas acuan, garis biru tua atas dan bawah merupakan batas atas dan bawah dengan penyimpangan $10 \%$. Hasil pengukuran uji banding menunjukkan bahwa mayoritas laboratorium berada pada rentang penyimpangan $\pm 10 \%$. Akan tetapi, ada beberapa laboratorium yang penyimpangannya $>10 \%$, LUR2 hasilnya $-12.8 \%$, bahkan ada satu laboratorium (laboratorium no 16) yang penyimpangannya cukup besar yaitu $+185 \%$ dibanding laboratorium acuan, datanya tidak dapat ditampilkan pada grafik gambar 5 karena nialainya jauh dari yang lain dan hanya ditunjukkan panah merah sebagai pertanda jauh dari skala Perbedaan nilai hasilpengukuran disebabkan oleh beberapa faktor antara lain karena tidak seragamnya jarak pengukuran (semakin jauh jarak detektor dan sumber, maka semakin minim efek sumpeak dan pile-up), aktivitas sumber standar antar laboratorium tidak sama (sebaiknya mendekati aktivitas sampel), pemilihan energi yang digunakan untuk menghitung tidak sama (sebaiknya memiliki intensitas besar dan energi di atas $300 \mathrm{kev}$ ), jenis detektor yang digunakan berbeda-beda, disamping itu perlu memperhatikan kebenaran nilai radioaktivitas yang tertera di sertifikat dengan mengkonnfirmasi dengan sumber standar yang lain.

\section{KESIMPULAN}

Interkomparasi pengukuran alat ukur sangat diperlukan untuk menjaga validitas hasil pengukuran. Dari hasil interkomparasi perigukuran spektrometergama yang dilakukan laboratorium PRR dan laboratorium lain di BATAN pada tahun 2012 ini mayoritas mempunyai penyimpangan $< \pm 10 \%$ dibanding aktivitas acuan. Pada awalnya hasil pengukuran PRR jauh lebih besar (5x) dibandingkan yang lain. Namun setelah ditelusuri ternyata kesalahan bukan karena penyimpangan alat melainkan karena kesalahan sertifikat sumber standar dan setelah dikonfirmasi dengan sumber standar yang lain (Ba-133, Co-60 dan Cs-137) ternyata aktivitas sumber standar Eu-152 adalah 1/5 dari nilai yang tertera di sertifikat dan hasil pengukuran aktivitas sampel $-12.8 \%$ lebih kecil dibanding laboratorium acuan.

\section{UCAPAN TERIMAKASIH}

Pada kesempatan ini Kami ucapkan terimakasih kepada Ibu Siti Darwati selaku Manager Puncak Laboratorium Uji Radioisotop dan Radiopfarmaka dan Bapak 
Gatot Wuryanto (PTKMR) selaku penyelenggara interkomparasi yang telah memberi kesempatan kepada kami untuk mengikuti interkomparasi antar laboratorium di BATAN dalam pengukuran radioaktivitas menggunakan spektrometer gama.

\section{DAFTAR PUSTAKA}

1. Ardisasmita M.S., Pengembangan Spektrometer Sinar-Gamma dengan Sistem Identifikasi Isotop Radioaktif Menggunakan Metode Jaringan Syaraf Tiruan". Risalah Lokakarya Komputasi dalam Sains dan Teknologi Nuklir (XII), (2002).

2. Anonimous, "Persyaratan Umum Kompetensi Laboratorium Pengujian dan Laboratorium Kalibrasi ISO/IEC 17025:2005". SN1 ISO/IEC 17025:2008, 29-30, BSN, (2008).

3. Achmad F, Rahayu S., Dan Sumarriani W., "Penerapan Grafik-X dan Grafik-R sebagai Grafik Kendali dalam Pengujian Kualitas Air", Laboratory of Experimental Station for Water Resources Environment Research Center for Water Resources, Jurnal Standardisasi Vol. 12, No. 1 Tahun 2010:14-19, (2010).

4. Wurdiyanto G., Pujadi, Dan Widodo S.," Interkomparasi Pengukuran Aktivitas Sumber Radioaktif Pemancar Gama ${ }^{152}$ Eu Di Lingkungan BATAN, Laporan Kegiatan, PTKMR-BATAN, Jakarta, (2012).

5. Suparman 1., Sunarhadijoso $S_{*}$, Wira $Y_{\text {., }}$ Rahman, Komputasi Kalibrasi Efisiensi, Control Chart dan Pengukuran Radionuklida pada spektrometri gamma, Lokakarya Komputasi dalam Sains dan Teknologi Nuklir: 6-7 Agustus 2008(225239), (2008).

6. Knoll G.F., Radiation Detection and Measurement, John Wiley \& Sons Inc.. New York, ISBN 0-471-07338-5, (2000). 